\title{
The MeRChANT AND THE KING POLITICAL MYTHS OF SOUTHEAST ASIAN COASTAL POLITIES
}

\author{
Pierre-Yves Manguin
}

\author{
"Maka kapal pun dapat dan dapati real \\ lima puluh laksa lain dagangan. Maka \\ baginda pun menjadi raja di Siantan."
}

Hikayat Raja Akil

The relationship between the rise of maritime trade and the formation and subsequent development of coastal polities in Southeast Asia has become the focus in recent years of many a study by archaeologists, historians, and anthropologists. ${ }^{2}$ The nature of this rela-

\footnotetext{
The final form of this essay owes much to the critical comments and suggestions of Oliver W. Woiters, William H. Scott, Jean-François Guermonprez, Bernard Sellato, and Jacques Leclerc. I wish to express my gratitude for all their help. It goes without saying that I assume full responsibility for its conclusions.

${ }^{1}$ From the unpublished Roolvink manuscript of the "Siak Chronicle" (Hikayat Raja Akil), as quoted by A.C. Milner, Kerajaan: Malay Political Culture on the Eve of Colonial Rule (Tucson: University of Arizona Press, 1982), p. 26. It translates as "A ship was captured and 500,000 dollars and other goods were taken from it; then the prince [who had been responsible for obtaining the booty] became raja in Siantan."

2 Among other such studies dealing with Insular Southeast Asia, see J. Wisseman Christie, "Markets and Trade in Pre-Majapahit Java," in Economic Exchange and Social Interaction in Southeast Asia: Perspectives from Prehistory, History and Ethnography, ed. K. L. Hutterer (Ann Arbor: Center for South and Southeast Asian Studies, 1977), pp. 197-212; J. Wisseman Christie, "Raja and Rama: The Classical State in Early Java," in Centers, Symbols, and Hierarchies: Essays on the Classical States of Southeast Asia, ed. L. Gesick (New Haven: Yale University Southeast Asian Studies Monograph 26, 1983), pp. 9-44; J. Wisseman Christie, "Trade and State Formation in the Malay Peninsula and Sumatra, 300 BC-AD 700," in The Southeast Asian Port and Polity: Rise and Demise, ed. J. Kathyrithamby-Wells and J. Villiers (Singapore: Singapore University Press, 1990), pp. 39-60; P. Wheatley, "Satyanrta in Suvarnadvipa: from Reciprocity to Redistribution in Ancient Southeast Asia," in Ancient Civilization and Trade, ed. J. A. Sabloff and G. C. Lamberg-Karlovsky (Albuquerque: University of New Mexico Press, 1975), pp. 227-83; P. Wheatley, Nagara and Commandery: Origins of Southeast Asian Urban Traditions (Chicago: University of Chicago Department of Geography Research Paper 207-208, 1983); O. W. Wolters, Early Indonesian Commerce: A Study of the Origins of Sri Vijaya (Ithaca: Cornell University Press, 1967); O. W. Wolters, History, Culture, and Region in Southeast Asian Perspectives (Singapore: Institute of Southeast Asian Studies, 1982); A. Reid and L. Castles eds., Pre-Colonial State Systems in Southeast Asia (Kuala Lumpur: Malaysian Branch of the Royal Asiatic Society, 1975).
} 
tionship is essential to the understanding of both the early formative stages of Southeast Asian statehood (sometime between the last few centuries of the first millennium B.C.E. and the beginnings of the first millennium C.E.) and subsequent state development. In very simplified terms the question posed boils down to the following: to what extent were local coastal polities a product of indigenous developments, and was overseas trade-interregional and later international-a major factor in this process?

Because of its subject matter, the present paper places itself at the center of this debate; indeed, it deals with the place of trade in the early phases of the development of coastal polities of Insular Southeast Asia, as perceived by themselves. Due to the category of sources used, the problem cannot be directly addressed in chronological terms: it threads through the relatively unexplored land that lies between history and myth as an attempt to explore and better understand, in the societies under consideration, what appears to be the very special relationship they maintained and encouraged between overseas trade and political power. What we will be dealing with is a historical process or mechanism, not actual, tangible events.

I shall start by summarizing a few tales. They all originate from coastal-pesisir-societies, and most of them were told or recorded in the harbor-cities on the Javanese, Balinese, Sumatran, or Kalimantan coasts.

We will first go to Buleleng, on the north coast.of Bali. ${ }^{3}$ The tale, according to the Babad Buleleng, runs as follows. A ship from overseas (banawa sunantara) got stranded (kandas) on the beach. The owner, Ki Mpu Awang, made an agreement: he would offer the whole cargo of the ship to whoever could put her back to sail. She was fully laden (sarat) with the finest products, cloth, [ceramic] dishes, plates, and bowls. After attempts by other people, Ki Gusti Pañji, with the help of his sacred kris and of the Gods, passed the test and put her back afloat. Ki Mpu Awang kept his word. Henceforth Ki Gusti Pañji possessed considerable wealth and, after some time, was consecrated as King Ki Gusti Ngurah Pañji.4

If we travel slightly west to Sumenep, in Madura, we find another story. On his way from Majapahit to Sumenep, Jokotole lived through various adventures. He met his father at his meditation place and learned that he would have to fight against an admiral from China named Dempo Abang (alias Sampo Tua Lang), who was said to show off his strength to all the kings of Java, Madura, and surrounding places. Jokotole fought Dempo Abang who had a ship that could sail on the sea as well as above mountains between clouds and sky. Jokotole himself rode a flying horse and managed to destroy the enemy's ship. He is said to have become the first historical ruler of Sumenep, under the name of Pangeran Setjoadiningrat. ${ }^{5}$

A Central Javanese lakon tells us about a prince of Java, from a country rich in rice, who entered into a competition with a shipmaster (juragan) from Banjarmasin named Dampu

\footnotetext{
${ }^{3}$ Relevant passages or motifs in the following stories are emphasized. It should also be noted at this point that the tales, as told in this paper, are selected episodes of much longer texts, the global meaning of which is clearly more complex than the one offered here for these particular episodes. For a broader analysis of the Babad Buleleng, see P. J. Worsley's introduction to his translation of the text, Babad Buleleng: A Balinese Dynastic Genealogy (The Hague: Bibliotheca Indonesia 8, 1972); also J.-F. Guermonprez, "Rois divins et chefs de guerre, variations et complexites des images de la royaute a Bali," L'Homme 95 (1985):39-70.

${ }^{4}$ Worsley, Babad Buleleng, pp. 145-47; for this and other versions of the Dampu Awang story, see also I Gusti Ngurah Bagus, Tokoh Dempu Awang dalam Dongeng Bali (Singaraja: Lembaga Bahasa dan Kesusastraan, 1966).

5 Abdurachman, Sedjarah Madura Selajang Pandang (Sumenep: np, 1971), pp. 10-11.
} 
Awang (alias Sampukong), who was asking for rice against his shipload of gold, jewels, and spices. The prince, of course, won the fight against the overseas trader and got the riches. ${ }^{6}$

We also learn from various legends that Ratu Kali Nyamat, the famous mid-sixteenth century queen of Japara, was established as the ruler after receiving help from a Chinese merchant whose ship had become stranded there. ${ }^{7}$

We now come to Cirebon, some time during the fifteenth century. The hero is Jeng Maulana. While traveling to China, he met the daughter of the Emperor, Putri Cina ("the Chinese Princess"). The Chinese ruler put him to a test. Jeng Maulana won and was subsequently expelled. However, the lady had fallen in love with the hero and she asked the emperor to be sent over to Cirebon to marry him; her father accepted and she went off together with a fleet of ships loaded with men, ceramics (guci, panjang), and all sorts of riches. All were duly accepted by Jeng Maulana: he married the princess and they had many children. Jeng Maulana eventually established the kingdom of Cirebon, which he ruled as the famous Sunan Gunung Jati (alias Sunan Cirebon). So, at least, goes the tale. ${ }^{8}$

Sumatra's west coast can also provide some examples of similar tales. One such example explains the origin of the name Minangkabau by the usual "victorious buffalo" motif. But it is associated with a theme by now familiar: the founding brothers of the kingdom, Dato' Katumanggungan and Dato' Parpatih see a ship coming ashore. It carries a gigantic buffalo. The captain (Nakhoda Besar) offers his ship and all her cargo to whoever can beat his buffalo in a fight. Using a young buffalo and a stratagem, the local people win the bet and are therefore given the ship and the shipload. After this, they rename their abode as Minangkabau and reorganize the polity. ${ }^{9}$

In Barus, the story runs with a twist, as follows: Guru Marsakot, one of the sons of the founding father of the polity, separates from his brother and moves to Lobu Tua, a site he

${ }^{6}$ S. Cohen, "Wajang Dampoe Awang," Tijdschrift voor Indische Taal-, Land-en Volkenkunde uitgegeven door het Koninklijk Bataviaasch Genootschap [hereafter TBG] 45 (1902):144-67; also, see references in note 13. The proposed exchange of the cargo for rice-a staple production of the Javanese hinterland-appears again in Sundanese episodes in connection with the myth of Sri, a goddess always associated with fertility and rice growing. Dampo Awang, however, appears right in the middle of the myth of origin for rice. He was a merchant who came from a country suffering from famine and tried to buy rice from Prabu Siliwangi; when the latter refused-rice should not be sold-Dampo Awang became angry and spread all sorts of plagues to destroy rice and other plants. Only divine intervention could defeat Dampo Awang and his allies and save cultivated plants. K. A. H. Hidding, Nji Pohatji Sangjang Sri (Proefschrift, Rijksuniversiteit te Leiden, 1929), pp. 34, 61 n. 1, 86 n. 1; V. Sukanda, Le triomphe de Sri en pays soundanais (Paris: École Française d'Extrême-Orient Publication No. 101, 1977), pp. 80ff; I wish to thank Viviane Sukanda for data on the Sundanese appearances of Dang Puhawang. This diversion of the rather profane shipmaster into the sacred world of origins appears to be unusual in Insular Southeast Asia. However, this branching into motives relevant for inland, agricultural polities should also be explored. The present paper cannot address this problem.

${ }^{7}$ Liem Thian Joe, Riwajat Semarang (dari djamannja Sam Poo sampe terhapoesnja Kongkoan) (Semarang: Ho Kim Yoe, 1934), p. 7; Th. G. Th. Pigeaud, Literature of Java. Catalogue Raisonné of Javanese Manuscripts in the Library of the University of Leiden and Other Public Collections in the Netherlands, 4 vols. (The Hague: Koninklijk Instituut, 1967-80), 2: 363; Th. G. Th. Pigeaud and H. J. de Graaf, De eerste moslimse vorstendommen op Java (The Hague: Verhandelingen van het Koninklijk Instituut voor Taal-, Land-en Volkenkunde [hereafter VKI] 69, 1974): 104-6, 271 n. 112.

${ }^{8}$ P. S. Sulendraningrat, Babad Tanah Sunda/Babad Cirebon (Cirebon: np, 1984), pp. 31-37. For historical background on Cirebon, see P. Abdurachman, ed., Cerbon (Jakarta: Yayasan Mitra Budaya/SH, 1982). Paramita Abdurachman (p.c.) heard a similar story from Buton, involving the local ruler, a Tartar (i.e., Chinese) princess and a shipwreck with a valuable cargo (said to be found in Selayar).

${ }^{9}$ E. Netscher, "Een verzameling van overleveringen van het rijk van Minangkabau uit het oorspronkelijk Maleisch vertaald," Indisch Archief 2, 3 (1850): 53-54. The tales published by Netscher carry a few more such motifs with variants; see, for instance, pp. 64-65. 
owns. He discovers Indian merchants (Ceti and Hindu) are already established there after their ship got stranded. They had attracted many foreigners (orang dari lain tempat dan segala bangsa) and the settlement had therefore become a prosperous settlement (negeri). Guru Marsakot decides to stay and rule over the land named Pansur. After he becomes the raja, the land grows even more prosperous and attracts trade from many overseas places. ${ }^{10}$

The same motifs are found again in Kutei. After the setting is prepared and the founding hero Aji Batara Agung Dewa Sakti and other characters are introduced, a Chinese prince sails into the harbor. He lures Aji Batara Agung into betting on a cockfight, which he loses. He thus has to surrender his ship, together with her cargo and crew. Aji Batara Agung builds a new settlement (pindah bernegeri), following which he sails to various places in Kalimantan and keeps acquiring riches (harta agung). ${ }^{11}$

Up in the Philippines, on the Island of Palawan, a tale recalls that there was once a conflict between the King of Brunei and a local hero as to who would rule over the island. After winning a bet against his Brunei rival, the Palawan contender gained five ships with their cargoes and consequently ruled over Palawan. ${ }^{12}$

One could go on narrating such tales, for there is quite a repertoire originating from the multitude of harbor-cities that have sprung up, at one time or another, along the coasts of the Java Sea, from Palembang to Buleleng, through Lampung, Banjarmasin, and the Javanese pesisir, as well as, seemingly, in other areas of Maritime Southeast Asia. ${ }^{13}$

At times, the stories appear only vaguely related and, as is often the case in a predominantly oral context, the characters or events undergo permutations that may obscure the contents of the tale, at least at first sight. However, a careful breakdown of their formative elements can bring to light the underlying and recurrent motifs: in other words, the structure of the tales. The tales above may easily be trimmed to the parts that interest us, i.e. into the seven following motifs (not all of these necessarily being always present in a single tale):

1. a local character has exceptional powers/sakti;

2. then comes an overseas ship fully laden/sarat with rich merchandise,

${ }^{10}$ J. Drakard, ed., Sejarah Raja-raja Barus: dua naskah dari Barus (Jakarta: École Français d'Extrême-Orient, Collection de texts et documents nousantariens, no. 7, 1988), pp. 81, 133.

11 C. A. Mees, ed., De Kroniek van Koetai (Santpoort: np, 1935), pp. 72-73, 140-53.

12 R. B. Fox, Religion and Society among the Tagbanua of Palawan Island, Philippines (Manila: National Museum Monograph No. 9, 1982), p. 18.

13 Th. G. Th. Pigeaud, Javaanse volksvertoningen, bijdrage tot de beschrijving van land en volk (Jakarta, 1938), pp. 81, 91, 192-95; and Pigeaud, Literature of Java, 2: 61, 495, 516, 850, 853, gives brief summaries of Javanese lakon and local legends of Dampu Awang. R.T.A.A. Probenegoro, "Djoeragan Dampoehawang," Djawa 21, 1 (1941): 1-11, also has various references to this theme, including some from the ketoprak repertoire. I have myself heard such stories told by fishermen in the Tuban area in 1983. On a different tales for Dampu Awang's occurrence: in Palembang, see L. C. Westenenk, "Boekit Segoentang en Goenoeng Mahameroe uit de Sedjarah Melajoe," TBG 68, 1 (1923): 222 (but he also is associated there with the Putri Cina and Chinese customs in local lore); in Lampung, see J. A. Du Bois, “De Lampongsche districten op het eiland Sumatra," Tijdschrift voor Nederlandsch-Indie 14 (1852): 245-75, 309-33; in Banjarmasin, J. J. Ras, ed., Hikayat Banjar, A Study in Malay Historiography (The Hague: Bibliotheca Indonesica 1, 1968), where Dampu Awang is the name of a sea-going merchant who is associated with a story different from that in our tales. H. O. Beyer, "The Philippines before Magellan," Asia Magazine (Oct.Nov., 1921), states that "the most reliable of the pre-Mahommedan traditional histories of Sulu states that the first civilized foreigners to establish a settlement in that island were the Orang Dampuan"; this appears to be some corrupt quotation from a comparable tale. In association with most of these tales, one finds explanations for local toponyms that carry names of boats (banka, jong, etc., or even the name Dampu Awang itself, as in Lampung) resulting from the events described in the tales. 
(3. usually under the captainship of shipmaster Dampu Awang, alias Sampo);

(4. the ship may get stranded/ $/$ kandas $^{14}$ and)

5. a competition takes place, either a fight or a bet, the prize of which is the ship cargo;

6. the local character, thanks to his sakti, wins over the riches in the ship and thus acquires considerable wealth, after which

7. he rules over his now prosperous country.

Before we start trying to understand the underlying meaning of such tales, some further motifs which appear to have been blended into the rich symbolism of Indonesian textile decoration and are clearly associated with the above tales should be investigated. These textiles have been found within the area where the tales were collected. These are not narrative motifs, but the statements they make can be read as "texts" in the very same way.

The first motif is the so-called jong sarat. The meaning of the phrase itself poses no problem: what we have here is a "fully laden ship," the same motif we encountered in the above tales. It always seems to be mentioned in relation with various rites of passage and-this is essential-with high-ranking or royal-blooded heroes. In Perak (Malaysia) we find mentions of a mat embroidered with the jong sarat motif, in an East Javanese Babad Blambangan it is a songket jong sarat, in the Malay Hikayat Dewa Mandu we get a kafan jong sarat and in Lampung there is a tampan jong sarat. ${ }^{15}$ Despite the fact that, in Lampung, depictions of sailing vessels are a common feature of textiles, the name jong sarat has no connection with such graphically obvious textiles: it is actually associated with a cloth that does not carry a ship design and is worn by the bride at marriage ceremonies. It is, however, richly decorated with gold thread and has valuable silver coins hanging from its lower side. ${ }^{16}$ What we have here, therefore, are "fully laden" pieces of cloth that were associated, in rituals, with wealth deriving from maritime trade.

The other textile motif I shall mention is still a popular pattern among pesisir people (mostly Cirebon and Indramayu): this is the pola kapal kandas, which translates as "stranded ship pattern." The story associated with it relates that this ship, which was not set afloat again, was that of the Putri Cina-therefore, as we have seen, it was a "fully laden" one. No wonder, then, batiks bearing the kapal kandas motif are still worn in special circumstances, where wealth and prosperity are asked for. The design of the motif is purely abstract (no kapal is represented) and were it not for the tale of the Putri Cina quoted above, it would be difficult to figure out its actual meaning. ${ }^{17}$

\footnotetext{
14 The acquisition by a ruler of the cargo of a stranded ship reminds one of the shipwreck laws current in Southeast Asian seas: the rulers automatically inherited the contents of the lost ship. But such laws are also common in the Indian Ocean, not to say universally, and I therefore do not believe that this coincidence is relevant. In any case, the stranding of the ship is not an essential motif in our tales.

15 On the jong sarat expression and an analysis of the broader meaning of ship motifs in textiles from Lampung and elsewhere, see P.-Y. Manguin, "Shipshape Societies: Boat Symbolism and Political Systems in Insular Southeast Asia," in Southeast Asia in the 9th to 14th Centuries, ed. D. G. Marr and A. C. Milner (Singapore: Institute of Southeast Asian Studies, 1986), pp. 187-213, and the references quoted therein.

16 I owe many thanks to the late Paramita Abdurachman for having taken the trouble to carry out her own personal inquiry on these textiles.

17 On the pola kapal kandas in Cirebon and Indramayu, see Abdurachman, Cerbon, p. 153. W. Warming and M. Gaworski, The World of Indonesian Textiles (Tokyo/New York: Kodansha International, 1981), p. 178, are mistaken when they say this motif is only found in Lasem; when they explain it by stating that "it was customary for villagers who helped push a beached ship back to sea to share in some of the wealth on board," they seem to have noted down and possibly misunderstood a local interpretation of the motif akin to the stranded ship theme. The
} 
An odd occurrence of the "fully laden boat" motif appears in the Javanese Kidung Angling Darma, as well as in other texts. These carry references to banawa sarat, the literal meaning of which is the same as jong sarat. Drewes discusses the use of the phrase but does not understand its appearance in the kidung to designate a house in a forest which is full of riches, a wealth that will be acquired by the hero of the tale. ${ }^{18}$ It is only in the comparison with other appearances of the sarat/"fully laden" motif that sense can be made of the banawa sarat phrase in this particular context. Except for the fact that the riches are referred to as a "ship (banawa) cargo," there is no reference here to sea-going trade. This raises questions about both Javanese perceptions of the forest and remanent maritime motifs in an essentially inland and agrarian context. Answers to such questions are beyond the scope of this essay.

One other aspect of these tales should be investigated. This is the name of the character who most often appears in them, though he is not the actual hero (a role reserved for the founder of the polity), i.e. Dampu Awang (and his aliases Sampo, Sampo Kong, Sampo Tua Lang, etc.). It is used in the examples above as a proper name, but its origin is in the Javanese title dang mpu hawang (or possibly in cognate forms in other related languages). Dang is an honorific prefix denoting persons of distinction, or high rank; $(m) p u$ has a similar usage; the title ( $h$ )awang conveyed among various Malay World people (Minang, Malays, etc.) the idea of a non-noble official of high rank, at times associated with shipmasters (nakhoda). This last meaning is precisely that of the title puhawang when it first appears in the Old Malay Sriwijayan inscription of Telaga Batu, dated from the last quarter of the seventh century C.E. It is often found again with the same meaning in late first millennium Malay and Javanese epigraphs, as well as in Old Javanese literature (in twelfth-century texts such as the Bharatayudha, the Smaradahana, or the Hariwangsa). So what we have in our tales is a character clearly bearing the title Dang Puhawang (turned into the proper name Dampu Awang by folk tradition) who has from early times been associated with shipping and trading at the highest level. He is not a petty trader: in the tales, he owns the ship and the rich cargo with which she is laden. Inscriptions make it clear the puhawang were part of the ruler's chosen retinue. In Central Java, they make offerings to royal sanctuaries (Dang Puhawang Gelis inscription of 827 C.E.). In East Java, enough revenue was derived from transactions with puhawang and merchants (banyaga) from other islands (dwipantara) to prompt the ruler into launching hydraulic works, so as to facilitate their mooring in Ujung Galuh (Kamalagyan inscription of 1037 C.E.). ${ }^{19}$

The other names Dang Puhawang is given in some of the tales, and never as obviously as in the Semarang tradition, are Sampo Kong or Sampo Tua Lang, etc. ${ }^{20}$ These are the

National Museum in Jakarta holds in its collections a dodot with the kapal kandas pattern said to come from Yogyakarta.

${ }^{18}$ G. W. J. Drewes, ed., The Romance of King Angling Darma in Javanese Literature (The Hague: Bibliotheca Indonesica 11, 1975), pp. 87 \& n 9, 329. I am grateful to Henri Chambert-Loir for having attracted my attention to this unusual example of the motif.

19 The best philological analysis of the term so far will be found in L.Ch. Damais, "Quelques titres javanais de l'époque des Song," Bulletin de l'École Française d'Extrême-Orient 50, 1 (1960):25-29. See also Manguin, "Shipshape Societies," pp. 197-99, to which one may refer for more references to existing literature on the subject.

20 On the Dampu Awang/Sampo tradition in Semarang, there is an abundant literature. One may refer to I. W. Young, "Sam Po Tong, La grotte de Sam Po," T'oung Pao 9 (1899):93-102; D. E. Willmott, The Chinese of Semarang: A Changing Minority Community in Indonesia (Ithaca: Cornell University Press, 1960); Oen Boeng Ing, "Het een en ander over Sam Poo Toa Lang of Kjiahi Dampoe Awang," in Supplement op Het Triwindoe-Gedenboek Mangkoe Nagoro VII (Soerakarta, 1940), pp. 221-23; Liem Thian Joe, Riwajat Semarang, pp. 1-10; Th. G. Th. Pigeaud and H. J. de Graaf, Chinese Muslims in Java in the 15th and 16th Centuries: The Malay Annals of Semarang and Cerbon 
clearly recognizable aliases of the famous Chinese historical character Admiral Zheng He, a Muslim who conducted seven great Ming fleets across Southeast Asia and the Indian Ocean between 1405 and 1433.21 Why this other great historical Chinese "shipmaster" became associated with our legendary Dang Puhawang (who carries an Austronesian name) can only be answered later in this paper, after the riddle of the tales is solved.

We therefore are presented with a set of folk-tales that were commonly popular among coastal societies of the western part of Insular Southeast Asia. These societies are relatively well known to historians, at least during the post-fifteenth century stages of their development. ${ }^{22}$ The social context of such tales may therefore be examined to investigate the "king and merchant" relationship, which appears so prominently in them.

A first step in this process will be to check what we presently know about trade-particularly with overseas merchants-and acquisition of wealth in Malay World political systems. We are fortunate to be able to refer to recent historians who have conducted their research by studying Malay texts, thus providing us with a referential relationship with the folk-tales under consideration.

What first comes to mind is that political power and wealth cannot be dissociated in a Malay World context. The symbolic value of the ruler's "treasure" is essential in this regard. Wealth is an attribute of the ruler, one of the requisite sources of his power (wealth, however, is not an accumulative process: it should flow towards the ruler as well as from him ${ }^{23}$ ). Now, in coastal polities or harbor-cities, where trade was the foremost economic activity, in societies where not only luxuries but above all the basic daily necessities were obtained through overseas trade, it would be normal to find among the requisite attributes and duties of a good ruler an ability to convene a sufficient number of traders into his harbor. In doing so, he would reinforce his sovereignty over potentially rival neighboring harbor-cities. Through this initiative, in proportion to the success of the trade, he would also generate income for his followers, and he would therefore accumulate prestige as the dispenser of material wealth. Milner, in fact, writes about the "excessive partiality for trade" among Malay rulers whose "kingdom was, in the final analysis, a commercial venture." Thomaz, basing himself on early sixteenth century Portuguese sources, portrays pre-Portuguese

(Monash: Monash University Papers on Southeast Asia No. 12, 1984); P. Pelliot, "Les grands voyages maritimes chinois au debut du XVe siècle," T'oung Pao 30 (1933): 257-58; P. Pelliot, "Notes additionnelles sur Tcheng Houo et sur ses voyages," T'oung Pao 31 (1935):280, 311; C. Salmon, "A propos de quelques cultes chinois particuliers à Java," Arts Asiatiques 26 (1973): 243-64; Amen Budiman, Semarang Riwayatmu Dulu, vol. 1 (Semarang, 1978 ): 8-35. 21 J.J.L. Duyvendak, "Ma Huan re-examined," Verhandelingen der Koninklijke Academie van Wetenschappen, afd. Letterkunde 32, 2 (1933); Pelliot, "Les grands voyages" and "Notes additionnelles."

22 As mentioned in note 2, many studies have been devoted to trade, state formation, and statecraft. The following paragraphs were mostly inspired by A. C. Milner's study of Malay perceptions of their kerajaan in nineteenthcentury Deli and Pahang; Milner, Kerajaan, particularly chapter 2, which deals with economic aspects. See also A. Reid, "Trade and State Power in 16th and 17th Century Southeast Asia," in Proceedings, Seventh IAHA Conference, Bangkok, August 1977 (Bangkok, 1979), 1: 391-419. Wolters, History, Culture, and Region, pp. 34ff discusses the importance of the notion of "treasure" for Southeast Asian rulers.

23 It is always when the flow of wealth is unidirectional, when there seems to be accumulation without redistribution, that the rich merchants of Java are accused of being helped by the malevolent genii named tuyul. 
Melaka in very similar terms: "everything in Malacca points to a market economy.... The State existed there because of trade, not trade because of the State." 24

The various conditions a potentially successful ruler would need to perfect the foundation of a coastal state could therefore be summarized as follows (this is done with a considerable measure of simplification: because of the theme of this essay, the economic aspects of kingship are artificially over-emphasized, leaving aside other crucial attributes such as ritual, kinship, etc.):

-being imparted with some measure of legitimacy and/or endowed with enough charisma (derived from "prowess," "divine radiance," "soul-stuff," or sakti) to build up local networks of alliance and exchange; 25

-assuming authority over a potential harbor-centered polity;

-luring in, retaining, and regulating overseas exchange at this site to provide external income (a variety of technical possibilities are offered: tap the economic resources of the hinterland, conduct entrepôt trade, etc.);

-mobilizing, manipulating, and redistributing the subsequent wealth as a political weapon, to extend his secular authority and attract a larger clientèle, thus achieving the desired state of ramai. ${ }^{26}$

A comparison of the list of structural motifs extracted from the Dang Puhawang tales with that of conditions set up in Malay literature for a ruler to be able to proceed with the foundation of a viable coastal polity will at once reveal striking similarities. The statement in the tales uses the language of a society, that of the pesisir harbor-cities of Southeast Asia or rather of two of their literary genres-"histories" and folk-tales-which this society uses to express and explain concepts that are critical to her. In this particular case, the statement is made to explain in symbolic or metaphoric terms the economic mechanism leading to the foundation of a state: the message carried by this particular episode, encountered in a wide variety of (more complex) texts, is that overseas merchants and trade are a prerequisite for the kind of prosperity (keramaian) considered befitting a successful polity. In the Hikayat Hang Tuah, it is said that the founder of the Melaka dynasty, shortly after descending from Heaven to Bukit Seguntang, became widely known as a king bestowed with many qualities, among which loomed large the fact that "he was very fond of all merchants"; Bukit Seguntang/Palembang is later said to have become a large country, "many merchants came and went to trade there. And all the people from countries without a raja congregated there."27 Curiously, Marco Polo's description of Java in the late thirteenth century rings a bell by now familiar: "This island is full of great wealth... And unto this land come very great numbers

\footnotetext{
24 Milner, Kerajaan, p. 16; L.F.F.R. Thomaz, "Malaca's Society on the Eve of the Portuguese Conquest: A Tentative Interpretation based on the Extant Portuguese Documents," Paper presented at the Persidangan Antarabangsa mengenai Tamadun Melayu, Kuala Lumpur (1986), p. 5.

25 For a discussion of these various attributes of power in Southeast Asia, see Wolters, History, Culture, and Region, particularly pp. 101-4.

26 The term ramai (or the form keramaian describing the state of being ramai) is the most common attribute of a successful kingdom. A Bengkulu folk-tale expresses this in a nutshell: Lama-kelamaan kampung menjadi ramai, dan hampir menjadi sebuah kerajaan ("As time passed the settlement became ramai and came short of becoming a kingdom."); Anonymous, Cerita Rakyat Daerah Bengkulu (Jakarta: Proyek Penerbitan Buku Sastra Indonesia dan Daerah, 1981), p. 113.

27 Hikayat Hang Tuah (Kuala Lumpur: Dewan Bahasa dan Pustaka, 1961), pp. 6, 9. The expression this text uses in many similar examples is dagang santeri, in a context where sea-going or "foreign" merchants are called for (as in kasantrian, the name of foreign quarters in harbor-cities such as Banten). See also note 38 below.
} 
of ships and of merchants who come there to trade and buy many goods there and make very great profit there and very great gain. There is so great treasure in this island that there is not a man in the world who could believe or tell or say it." 28 It is admitted by now that Polo never actually sailed to Java and he may well have heard this description from the mouth of Southeast Asian merchants in North Sumatra, where he spent some time. This would explain the striking similitude with local statements. The same could be said about Tomé Pires' hearsay remark on Demak in the mid-1510s: 'because ... [Demak's ruler] has not done any trade for three or four years he is greatly exhausted ... and the people are already leaving his land for other places because there is no trade in merchandise."29

One element of the tales still needs elaboration: why has Dang Puhawang, a character with an Austronesian name (or title), been given the name of, or been assimilated with a well-known Chinese historical character? Dang Puhawang is, by trade, a ship-master who arrives from "overseas," literally from across a sea. Depending on the context of the tale, this notion of "overseas" may be left with its vague definition (as in sunantara), or it may be given a more precise connotation: the overseas merchant may come from other harbor-cities within the Malay World (Banjarmasin, Aceh, etc.) or from countries across the China Sea or the Indian Ocean (generally China or Keling). In a word, he is a sabrangan, somebody who has crossed over the seas (though I have not found in the above tales this particular term, common in Javanese lakon for overseas characters). The emphasis in the tales is therefore on "overseas," not on a determined place of origin: the shipmaster in the tales may stand for inter-regional (i.e. essentially Malay World) as well as "international" traders (including Chinese), both of which would be part of a suitable trade network. Early epigraphy-particularly that of East Java-appears not to distinguish among merchants from "international" and inter-regional backgrounds: the classification of traders is functional, not based on place of origin. In later Malay literature the presence of numerous foreign merchants is conventionally seen as a desirable feature in a polity. ${ }^{30}$ Maritime trade is the main source of income of harbor-centered polities and, by nature, this can only be "overseas" trade.

The answer to the Sampo riddle therefore lies in the economic role played by China and the Chinese market in Southeast Asian history. No factor in the international environment of harbor polities in the region would have been more significant than overseas trade with China, whether it was conducted by Southeast Asians themselves or by Chinese. ${ }^{31}$ Yet another tale relates that the ruler of Kan-to-li, a trading kingdom somewhere on the shores of the Malay Peninsula or South Sumatra, had a dream in 502 C.E.: if he would send tribute (i.e. trading) missions to China, his land "would become rich and happy and merchants and travelers would multiply a hundredfold." Though recorded by a Chinese chronicler, this dream of a southern king bears a striking resemblance to the statements we have come across in local tales and provides a vivid illustration of the osmosis between the two markets at the northern and southern ends of the South China Sea. In the eleventh century, in a

28 A. C. Moule and P. Pelliot, eds., Marco Polo. The Description of the World, 2 vols. (London, 1938), 1: 368.

${ }^{29}$ A. Cortesão, ed., The Suma Oriental of Tomé Pires, 2 vols. (London: Hakluyt Society, 1944), 1: 186.

30 Christie, "Markets and Trade," pp. 204-9; Milner, Kerajaan, p. 23 and n. 82.

31 The ups and downs of pesisir states (including such prominent polities as Sriwijaya and Melaka), and their close relationship with the fluctuations of the Chinese overseas trade have been studied in detail by Wolters in his two books on the rise and fall of Sriwijaya: Early Indonesian Commerce, already cited, and The Fall of Srivijaya in Malay History (Kuala Lumpur: Oxford University Press, 1970); also Wang Gungwu, "Early Ming Relations with Southeast Asia: A Background Essay," in The Chinese World Order, ed. J. K. Fairbank (Cambridge: Harvard University Press, 1968), pp. 34-62. 
pragmatic but nonetheless evocative statement about Sriwijaya, a Chinese chronicler writes: "Merchants from distant places congregate there. This country is therefore considered to be very prosperous." Closer to us, we know that Chinese overseas activity and patronage-at the precise time of the great naval expeditions of the Ming under Zheng He-were crucial in the launching of the early kingdoms of Pasai and Melaka. ${ }^{32}$

It is no wonder, then, that a character such as Zheng He (alias Sampo, i.e. Sam bao, the "Three Jewels" eunuch) would be remembered in local lore by those who stood to gain from the increased economic activity as an expeditor of trade, hence a promoter of wealth and political power, hence a replication of Dang Puhawang. The fact that the Ming expeditions were carried out with such considerable pomp, with fleets of dozens of enormous ships loaded with merchandise, could only have further stamped the imagination of pesisir populations in Southeast Asia. By coincidence (?), the Ming Chinese called their huge junks "treasure-ships" (bao-chuan), a striking rejoinder to the ships "fully laden" with riches of the Dang Puhawang tales. Moreover, these memories were further cultivated among an economically active and well integrated Chinese merchant community: in Melaka, in Semarang, in Jakarta, they kept the Sampo cult alive, blending local and Chinese statements into one single story. The appropriation by the Chinese community of the local Dang Puhawang theme parallels that of the recuperation in the temples they dedicated to Sampo of indigenous cults rendered to local kramat. ${ }^{33}$ In a sense, therefore, this very appropriation confirms the interpretation of the Dang Puhawang tales.

In a second step, one may find another transformation of the above motifs in some texts, at times in combination with the "real" Dang Puhawang motif. In the Hikayat Raja-raja Pasai, for instance, ships loaded with regalia coming from Mecca are found among the various elements that consolidate Malik al-Saleh's power over the harbor-state. During this Islamic moment of the Archipelago, when a new "age of commerce" and the expanding Islamic consciousness were indiscernible, it would appear that the political statements made in "historical" literature had their emphasis shifted towards religion: legitimization had now to come from the Caliph. Transformation of the myth to accommodate Islam was facilitated by the fact that the trader and the preacher of the Islamic faith were, by then, more often than not one single person. But the "treasure-bearing merchant" motif-in a debased form-still appears in the Hikayat Raja-raja Pasai immediately after lip-service has been paid to the new "mentalité": a trading ship from the land of Kalinga carries a man who has the power to detect reefs of gold and, sure enough, gold is then found in great quantities, and Malik al-Saleh's polity is accordingly bolstered. ${ }^{34}$ A similar variation on the theme-with a humorous twist - can be found in a folk-tale from Kalimantan Selatan: Datu Baduk is a learned jin who sails from Mecca on board the ship of Haji Muhhammad Arsyad, returning from studying Islam in the Holy Land to spread the new religion and to become an adviser at the Banjar court. The ship gets stranded (kandas); it turns out that the jin ulama is responsible for holding the ship immobile. He only releases her after it is agreed that he shall be

\footnotetext{
32 Wolters, Early Indonesian Commerce, p. 165; O. W. Wolters, "A Few and Miscellaneous pi-chi Jottings on Early Indonesia," Indonesia 36 (1983): 55; Wolters, Fall of Srivijaya, especially chapter 11 and appendix C.

33 Salmon, "Quelques cultes"; C. Salmon and D. Lombard, Les Chinois de Jakarta: temples et vie collective (Paris: Etudes insulindiennes-Archipel No. 1, 1980), pp. 86ff.; C. Salmon and D. Lombard, "Islam et sinité," Archipel 30 (1985): 73-94.

34 A. H. Hill, ed., "Hikajat Raja-raja Pasai," Journal of the Malaysian Branch, Royal Asiatic Society 33, 2 (1960): 123.
} 
authorized to settle in Banjar, where he will be revered and will teach the Religion to nonIslamic jin. ${ }^{35}$

One should also elaborate on a recurrent motif of these tales, that of the competition between king and merchant. Its outcome is positive (the founding of the polity), but it is clearly a conflictive rapport. Does the historical context in which these tales were produced provide elements that would allow us to decipher this motif? As discussed earlier, the title associated with our merchant, hawang, is that of a non-noble but high-ranking class in Malay World societies often associated with ship-masters (nakhoda/puhawang/juragan), trade and wealth. One social class in such societies-as known from post-fifteenth century sourcesthat immediately comes to mind is that of the ubiquitous and often all-powerful orangkaya. A lot has been written on their role and position, and this is not the place to elaborate again on the subject. Suffice it to say that, in the sixteenth to eighteenth centuries, the orangkaya merchant class was the mainstay of many societies of Insular Southeast Asia. But it has also been a constant threat to the power of the ruler. Exactly like the folk hero Dampu Hawang, the orangkaya could both do and undo a king. Too much wealth on their part was usually felt as a threat to the ruler's own power, challenged as it was by the rise and parallel development of commercial elites. Beaulieu, who visited Aceh in the early seventeenth century, puts this in concise but appropriate terms: the orangkaya usually lost their life when the king became suspicious of two circumstances, "their good reputation among the people and their wealth." 36 Earlier in time, in fact in the first ever written mention of a puhawang in a late seventh century C.E. Sriwijayan inscription, the ship-master class appears among those who threaten the "treasure" of the ruler (and, interestingly enough, they are among the few that bear an Austronesian, non-imported, title). No doubt, if merchants stopped patronizing a harbor-city, the ruler's "treasure" would rapidly fade away. Similarly, in an inscription from Champa dated 797 C.E., merchants are mentioned, together with warriors, brahmins, and ministers, among those prone to steal the riches of the polity. ${ }^{37}$ This ambivalence of merchants is possibly what prompted the author of a ninth century Javanese inscription to classify them among migratory birds: they were unattached, liable to transfer their trade activities to a rival harbor-city, hence dangerous. ${ }^{38}$ Again, a similar notion could have been conveyed by the 1079 C.E. Sriwijayan inscription at Canton which describes merchants as "flying." 39

It therefore appears that the competition motif can itself be explained when the context of the tales is examined and reference made to the dialectical relationship between ruler and

\footnotetext{
${ }^{35}$ Anonymous, Cerita Rakyat Kalimantan Selatan (Jakarta: Proyek Penerbitan Buku Sastra Indonesia dan Daerah, 1981), pp. 92-95.

36 A. Reid, "Trade and the Problem of Royal Power in Aceh, c. 1500-1700," in Pre-Colonial State Systems in Southeast Asia, ed. A. Reid and L. Castles (Kuala Lumpur: Malaysian Branch of the Royal Asiatic Society, 1975), pp. 4555; Reid, "Trade and State Power"; J. Kathirithamby-Wells, "Royal Authority and the Orang Kaya in the Western Archipelago, circa 1500-1800," Journal of Southeast Asian Studies 17, 2 (1986): 256-67; Beaulieu's quotation is from his Mémoires, as published in M. Thevenot's Relations de divers voyages ... (Paris 1696) 1: 109ff.

37 L. Finot, "Notes d'épigraphie VII: Inscriptions du Quang Nam (i: Première stèle de Dong-duong)," Bulletin de l'École Française d'Extrême-Orient 4 (1904): $91,95$.

38 J. G. de Casparis, Prasasti Indonesia II (Bandung: Masa Baru, 1956), pp. 2 n. 12, 326. One should note here that Casparis' clarification on the obscure verse that regroups birds (of the migratory sort) and merchants is only tentative. Could the term santeri used in classical Malay literature with a possible connotation of "wandering" be a reminiscence of this "migratory" trait of sea-going merchants (see above note 27)?

${ }^{39}$ Tan Yeok Song, "The Sri Vijayan inscription of Canton (AD 1079)," Journal of Southeast Asian History 5, 2 (1964): $17-24$.
} 
merchants in harbor-centered polities. This in turn further confirms the analysis offered here.

The exact nature of these stories that I have, for convenience sake, called the Dang Puhawang tales should at this stage be examined in more detail. As told in available literature (oral as well as written), they appear to belong to two genres: chronicles of the babad, sejarah, or hikayat type (therefore a local "historical" genre) and plain folk-tales (the latter closer to an oral, more popular tradition, but having nevertheless been transformed while passing into a written form). In whichever literary genre they have been transmitted to us, the underlying motifs always relate to that event of momentous importance for the narrator, i.e. the foundation of the polity he is telling us about. This is an event which can only happen once in his story, which is a "history" of that particular polity. I therefore believe that such tales should be interpreted as desacralized, transformed political myths of tradeoriented pesisir states. Their function would have been to elicit the legitimacy of the ruler's power and, as far as the Dang Puhawang motif is concerned, to clarify the position of a specific social group, that of the merchants, within the society. ${ }^{40}$ The episode of the Babad Buleleng, possibly the most elaborate and eloquent of those we found, no doubt points in that direction. ${ }^{41}$ The court rituals that may have been associated with such myths appear to have long disappeared in the societies under consideration. But the association of the "fully laden" or "stranded ship" motifs with textiles that remained until recently very much part of state or rank-related rituals is another indication of the origins of such tales.

Ceramics are often mentioned among the goods obtained after the competition described in the tales (where they usually appear as piring or piring panjang). The use of imported ceramic dishes in a variety of court rituals, as well as in the decoration of buildings found in harbors along the Javanese pesisir, has been routinely but loosely associated with past overseas trade. However, when attention is paid to the constant reference to such ceramics in jong sarat cargoes, a close correlation with the popular tales quoted above is inescapable. Gifts of ceramics loom large in foreign relations of Southeast Asian polities with overseas powers, mainly China. To quote just one example, the Hikayat Banjar lists among other gifts brought back by an embassy to China, "a thousand large bowls, a thousand small bowls, a thousand plates of various colours." It is remarkable in this context that ceramics still used in rituals at various courts in Central or pesisir Java, as well as in other islands (Sulawesi, Kalimantan, Maluku, Mindanao, etc.) are consistently said to be ancient

\footnotetext{
40 On the historical origins of tales and the transformation of myths into profane tales or "histories," see C. LéviStrauss, Anthropologie structurale deux (Paris: Plon, 1973), particularly chapters 8 (an analysis of Propp's Morphologie du conte) and 14 ("Comment meurent les mythes?"); V.J.A. Propp, Les racines historiques du conte merveilleux (Paris: Gallimard, 1983); G. Condominas, "Le souverain époux de son peuple: variations madécasses sur un thème malais," in Variant Views: Five Lectures from the Perspective of the "Leiden Tradition" in Cultural Anthropology, ed. H.J.M. Claessen (Leiden: ICA Publicatie No. 84, 1989), pp. 39ff ("La triade mythe, ethnologie, histoire"); P. E. Josselin De Jong, Ruler and Realm: Political Myths in Western Indonesia (Amsterdam and Oxford: Mededelingen der Koninklijke Nerderlandse Akademie van Wetenschapen, afd. Letterkunde, Deel 43/1, 1980); P. E. Josselin De Jong, "Myth and non-Myth," in Man, Meaning and History, ed. R. Schefold, J. W. Scholl, and J. Tennekes (The Hague: VKI 89, 1980), pp. 109-28.

41 Worsley, when editing the text, understood it as such (Babad Buleleng, p. 25); Guermonprez ("Rois divins," pp. 44-45,50-51) concurs in his study of Balinese perceptions of kingship: he writes about a "prosperity contract" between the ruler and his people.
} 
imported pieces, and, in places (Imogiri), more precisely gifts from foreign rulers. ${ }^{42}$ Having some of these ceramics inlaid into the walls of important buildings must have been tantamount to making a statement akin to that conveyed by the Dang Puhawang tales, or better to "illustrate" such a statement. ${ }^{43}$ Foreign textiles also appear prominently in lists of goods traded or received from overseas and we also know how important they were in rankrelated and other rituals. Goods acquired in shipments from overseas were thus naturally incorporated into the sign system of the society that produced the "fully laden junk" tales.

The existence of such trade-biased political myths underscores the fact that commerce played a prominent role in the early formative stages of coastal, harbor-centered political systems. Since what myths describe is a process-not an event-we are left with the problem of chronology. Is it possible, from the evidence at hand, to provide these myths with some sort of chronological depth, i.e. with a measure of referentiality to historical events? Is the process explained by the myth a recent one, that would for instance have taken place only during the fifteenth-seventeenth century economic boom of Southeast Asia? If so, this would substantiate the emergence of a new mercantile ethos in association with-as often claimed-this modern "age of commerce." 44 Or has this process been central to local societies from much earlier times?

The fact that practically no referential readings are available for pre-modern times may be only a reflection of the extreme scarcity - both quantitative and qualitative-of prefifteenth century sources that may be of use in textual interpretations. In no way does this paucity of sources allow us to conclude that the emergence of the Dang Puhawang motif is contemporary with the first texts that include the above tales. Indeed, I have quoted earlier in this paper a few first and early second millennium C.E. references that fit in closely with the motifs in the tales. That of the Kan-to-li ruler's "dream" about trade and associated wealth is particularly relevant in this context. This in turn points to the earliness of the process explained in such myths. I also identified two specific clusters of transformations undergone by the motifs that can be traced down to the fifteenth-sixteenth century period (which corresponds to trade expansion and to the rise of Islamic consciousness): the Sam $\mathrm{Po} /$ Zheng He variation and the shift of the legitimization process towards Mecca and Islamic values. Such transformations can only have been initiated when the producing societies further elaborated on their myths, generating a new set of referents within a pre-coded narrative. The myth must therefore have antedated this elaboration and cannot merely be a by-product of this recent "age of commerce." 45

However, for such a conclusion to be given a firmer recognition, one would need to investigate the relationship of the above motifs with seemingly comparable ones that appear

\footnotetext{
$42 \mathrm{~S}$. Adhyatman, Antique ceramics found in Indonesia, various uses and origins (Jakarta: The Ceramic Society of Indonesia, 1981), pp. 142ff., describes in detail the traditional use of ceramics in a variety of rituals as well as in decoration. For the Hikayat Banjar passage, see Ras, Hikayat Banjar, pp. 258-59.

${ }^{43}$ Surviving buildings that bear testimony to this practice are mainly religious--the burial complex of Sunan Bonang at Tuban, that of Sunan Gunung Jati at Cirebon, etc.-but texts point to a much broader usage of this type of decor in court buildings: in the Serat Arok, Vietnamese ceramics (piring Koci) are said to have decorated the palace of the adipati of Surabaya; S. Robson, "The Serat Arok," Archipel 20 (1980): 293.

44 D. Lombard, "Le sultanat malais comme modèle socio-économique," in Marchands et hommes d'affaires asiatiques dans l'Océan Indien et la Mer de Chine, 13e-20e siècles, ed. J. Aubin and D. Lombard (Paris: Editions de l'EHESS, 1987), pp. 117-28; A. Reid, Southeast Asia in the Age of Commerce, 1450-1680, Volume One: The Lands below the Winds (New Haven and London: Yale University Press, 1988); A. Reid, "An 'Age of Commerce' in Southeast Asian History," Modern Asian Studies 24, 1 (1990): 1-30.
} 
to be found in other, mainly Eastern Indonesian perceptions of similar or less elaborate exchange systems. ${ }^{46}$ I would submit as a working hypothesis that these myths could possibly be generated when the economy of a society crosses over the border between simple forms of exchange-restricted to kin-ordered, alliance, or tributary modes-and wider ranging networks in closer connection with market forces and, ultimately, with world economies. Jan Wisseman Christie convincingly argued that an active participation in interregional and later international trade networks would have been at the origin of state formation process in the Melaka Straits and Northern Javanese pesisir as early as the turn of the first millennium C.E. 47 . The dramatic broadening of the espace social brought about by such a direct involvement in far-ranging trade networks would then naturally have given birth to myths that established an explicit relationship between sea-going merchants, trade, and the founding of a viable polity.

45 These variations on the older Dang Puhawang theme may well have been conscious manipulations for political use by social participants; on such manipulations, see Josselin de Jong, "Myth and non-Myth," p. 115.

46 Comments on an earlier version of this paper suggested a relationship between the "cargo" in the jong sarat motif and cargo cults of Melanesia. I believe this is only a superficial resemblance. Nowhere in the Puhawang myth is there a messianic connotation (despite the fact that messianic or millenarian movements are common in Indonesia). The acquisition of the "cargo" is only one among many other prerequisites for state formation and development in Southeast Asia. This acquisition is not thought of as a means to obtain "wealth" comparable to that of a dominant force (the intruding "whites" in the Melanesian cargo cult). Finally, the Puhawang myth is in no way central to the formation of a full-fledged cult. A reverse proposition may, however, be conceivable: the modern cargo cult may actually have evolved on a favorable terrain where myths comparable to those of Southeast Asia would have been present.

47 Christie, "Trade and State Formation." 